\title{
The Ancient History and the Female Christian Monasticism: Fundamentals and Perspectives
}

\author{
By Paulo Augusto Tamanini*
}

This article aims to discuss about the rediscovery and reinterpretation of the Eastern Monasticism focusing on the Female gender, showing a magnificent area to be explored and that can foment, in a very positive way, a further understanding of the Church's face, carved by time, through the expansion and modes of organization of these groups of women. This article contains three main sessions: understanding the concept of monasticism, desert; a small narrative about the early ascetic/monastic life in the New Testament; Macrina and Mary of Egypt's monastic life.

\section{Introduction}

The nomenclatures hide a path, and to understand the present questions on the female mystique of the earlier Christian era it is required to revisit the past again. The history of the Church, Philosophy and Theology in accordance to their methodological assumptions, concepts and objectives, give us specific contributions to the enrichment of this comprehensive knowledge, still opened to scientific research. If behind the terminologies there is a construct, a path, a trace was left in the production's trajectory whereby knowledge could be reached and the interests of research cleared up. Once exposed to reasoning and academic curiosity it may provoke a lively discussion about such an important theme and incite an opening to an issue poorly argued in universities.

In the modern regime of historicity, man and woman can now be analysed based on their subjectivities and in the place they belong in the world and not only by "the tests of reason", opening new ways to the researcher to understand them. Nowadays, human sciences and theology are interested in understanding man and woman in their totality, in their cultural genders roles, in their mystique dimension, and, why not, in their relationship with the Transcendent ${ }^{1}$. Thus, it is not only important to recognise the existence of the male and the female monasticism, but that both passed through many adjustment processes according to time and space, whereupon have emerged some peculiarities. As a consequence, the East and the West preserve two aspects similar to Christian monastic life, each one with its own values, rules, and spiritual richness, associated with the same goal: to achieve perfection, human deification, through professing vows.

Once the Eastern and Western monasticism cannot be understood as an unchangeable reality in its male and female portions, investigating this

\footnotetext{
${ }^{*}$ Research Professor of the Post-Graduation Program in Teaching (POESENSINO), UFERSA (Rural Federal University of Semi-Árido), Brazil.

1. G. de Nissa, La mujer como evangelizadora [The woman as evangelist] (Buenos Aires: Lumen Ed, 1990).
} 
permanent interchange of time and space gives the opportunity to learn not only about its continuous rearrangements and ruptures, in the approximations and purposes, but also to know about how it has been announced and presented to the world, giving another identification to what we believed to be an offshoot of the true philosophy. According to Peter Brown, despite the fact that the monks of early Christianity lived away from the world, they did not dispense it totally, since their livelihood resources was supported by the mundane contact. In exchange for food, they offered manual work, spiritual counselling, and herb teas recipes for curing some

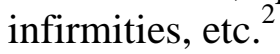

The works of the ancient monasticism, especially the Apophtegmas, not only condense the reports about the life of Anthony (or St. Anthony), Ammonius, Pachomius, Basil, Horsiesos, Theodorus, Theodorus Alexandrian, Evagrius, Palladius and Cassian $^{3}$ but also emphasize the existence of a portion that was not part of academic research interests, but since the nineteenth century has been rising to prominence: the female monasticism of byzantine tradition ${ }^{4}$.

\section{How Theologians and Historians Understand Monasticism?}

Dense shadows surround the origins of the Christian monasticism. Perhaps the veiling, the uncertainties, and the numerous probabilities to explain the roots of this regimented way of life excited the curiosity of the researchers. Historians, sociologists, theologians, philosophers, as well as those who aimed to follow those practices have discussed the several investigative possibilities. However, regardless of an examination in relation to the beginning of the Christian monasticism, presently, the preoccupation of some researchers is trying to enlighten people's lives, in its entirety, who were also inclined to the human susceptibilities and that have fought against demons, aiming to perfection. The monasticism is not an exclusive reality of the Christianism nor an ascetic way of life founded by it. Prior to the Christian model, there were pre-Christian communities of Greek, Israelite and Hindu traditions, which practiced communal forms of asceticism. ${ }^{5}$

Since every emergence carries a great deal of history, perhaps due to affinity, the East Christian has inherited from Judaism the monastic typology practiced in early Christianity and organized by the holy fathers. Currently there is no impediment to affirm that much before the emergence of the Christian monasticism, many others existed, what confirms this as a

2. P. Brown, "The rise and function of the Holy Man in late antiquity," in Journal of Roman Studies 61(1971): 80-101.

3. G. M Colombas, El monacato primitivo [The primitive monasticism] (Madrid: Christian Authors Library, 2004), 3.

4. P. F. Knitter, Introduzione alle teologie delle religioni [Introduction to the theology of religion] (Rome: Queriniana, 2012), 8.

5. A.Masoliver, Historia del monacato cristiano, III. El monacato Oriental. El monacato feminino [The History of the Christian Monasticism. III. The Eastern Monasticism. The Female Monasticism] (Madrid: Encuentro Ed, 1994). 
human phenomenon that the religions knew how to appropriate artfully. Usual words in Christian communities have been compiled in non-Christian territories, demonstrating that sources belonged to other realities of faith: askesis (ascetic); anakoresis (separation), koinobion (common life). ${ }^{6}$

The interest of European researchers - who have edited, translated, collated and catalogued what the medieval religionists collected about the life and writings of the monks and nuns of the eastern coenobitism earlier subsidized a collection of reports and literary compositions called monastic sources offered to everyone interested in seeking burning issues. Due to the diversity of the theme, new lectures emerged from different academic schools, allowing other monasticism views to be acknowledged. The rediscovery or reinterpretation of the eastern monasticism focusing on the Female gender came out as a magnificent area to be explored and that can foment, in a very positive way, a further understanding of the Church's face, carved by time, through its place of expansion and the modes of organization of these groups of women. ${ }^{7}$

If the first systematized information about the life of the monks came from St. Athanasius and St. Jerome, many others discussed about the anchorite monks from Egypt whom dedicated their lives to praying, composition and transcription of texts. Sources reveal that the nuns were copyists of the liturgical compositions, what was new and a paradigm break instituted by the gender culture. ${ }^{8}$

That being said, the monks in the earlier Church were more than ecclesiastic identifications, they were expressions and reflections from identities, revealing how these religionists understood themselves, as owners of a mission and as members of a church. The isolation, oriented by the philosophical motivation, manifested the world's escape, which accredited the mode of life in loneliness and contemplation. These ways of relationship with the knowledge, with the "true philosophy" and with the "eternal" contributed to the process of formation of the Church as the holder of the institution of the sacred. However, the search of these values characterizes strongly the contemplative way of existence of the Christian communities in the Greek east and Latin west. ${ }^{9}$

A group which clearly was in accordance with the mode instituted about how to behave towards a society, or that fled from persecutions, the first monastic movements or "escape movements to the Egyptian desert" or

6. G. M. Colombas, El monacato primitivo [The primitive monasticism] (Madrid: Christian Authors Library, 2004), 11-14.

7. A. Masoliver, Historia del monacato cristiano. I. El monacato desde los origines hasta San Benito [The History of the Christian Monasticism. I. The monasticism from its origins until St. Benedict] Madrid: Encuentro Ed, 1994.

8. C. Levalois, Prendre soin de l'autre: une vision chrétienne de la communication [Taking care of others: a Christian vision of communication] (Paris: CERF Ed., 2012), 32.

9. R. Amaral, A santidade habita o deserto: hagiografia à luz do imaginário social [The holiness inhabits the desert: hagiografy in the life of the social imaginary] (Sao Paulo: Ed UNESP, 2009). 
"world rejection" were regarded for the researchers as a reflection and an affiliation to an inverted life. ${ }^{10}$

A place of protest, reclusion and materialization of the denial to a way of feeling in a world that offered experimentations and material desires, with its structures and organization enchainment's, the desert became, firstly, the emblematic place to cultivate in men and women the propensity to holiness; a place of improving and of affirmative answer to a mode of living that the Christian community, which was rising, proposed to live.

The desert is, in the revelation of the Old and New Testaments, a particular attractive theme. We know that in the Hebrew mythology the Hebrews had in the desert the immediate experience of God's presence, and in that place, they had to fight for the purity of their devotedness, for the fidelity to their God. However, it was also in the desert that the chosen people experienced sin and offended the Creator, to the point that the place became a symbol of absence, loneliness, full of dangers and temptations. The New Testament also brings this double vision. It is in the desert that John the Baptist begins the proclamation of the Kingdom of God, and where the persecuted Church of Revelation runs to (12.5 to 6). ${ }^{11}$ The lonely mountain is also Jesus's favourite place to pray. Nevertheless, the desert is, moreover, the demon dwelling, obscure and lifeless symbol. Jesus was tempted in the desert, and according to his own teaching, this is the proper place of temptation. Whatever it is the origin of this double image of the desert, the essential is that a part of the paradox of all that shapes the relationship of God with man. In addition, the desert reminds the man his poverty and essential solitude, which makes it possible to understand the wealth of creation and the grace that means the community and service to men. ${ }^{12}$

If it was a place of dispossession, a place of detachment, and replacement of values, it also seemed to be a space for learning and selfawareness for women and men who dared to cross it. The desert as a master of what was essentially human, became gradually a place that conducted to contemplation, a reference to centres of pilgrimage, a place of worship and where you could discover and work out an individual spirituality. The construction of the image-symbol of the desert, instituted and called hermitages, monasteries, cultivation, were gathering strength and legitimacy through the interest, organization, regulations and speeches of the Church Fathers (also known as "Holy Fathers ", mostly bishops), first Greek, then Latin.

10. P. F. Knitter, Introduzione alle teologie delle religioni, 2.

11. Bíblia de Jerusalém [Jerusalem Bible] (Sao Paulo: Paulus Ed., 2008).

12. C. Rapp, Holy Bishops in late antiquity: the nature of christian leadership in an age of transition. The transformation of the Classical Heritage, 37 (Berkeley and Los Angeles: University of California Press: 2005). 


\section{The New Testament and the Female Monasticism}

The Saint Greek Fathers of the Church insisted that the Bible was not a sui generis pile of writings, but the history of God's relationship with a community of faith. Therefore, they understand the Scriptures as an essential part of the Holy Tradition. The apostolic witness offered a new perspective on how the Word of God should be understood in the development of what became the doctrine of the Church. These doctrines clearly reflected how Scripture was the foundation of tradition. ${ }^{13}$

In the Letters of Saint Paul, for instance, it is often the emphasis on the Church being Christ's Mystical Body and that everyone constitutes it, emphasizing that Christ is the head and the Holy Spirit its soul (Colossians 1,18 ). Beyond concepts that prioritize exclusively the logic, the reason, in detriment of the feelings and emotions, attributions inherent to the human being are also present.

For this reason, the Church is not only an organic structure; it is an organization responsible for conveying the Message of Salvation and spiritual wellness to men, women, young people, children, the elderly and adults. Thus, it is, originally, the place par excellence of opening, of inclusion with no predilections of race, ethnicity or gender. Despite the fact that men stand out in its hierarchical structure, the current theology tries to give visibility to those who were forgotten for a long time. According to Andrew LOUTH, the strong heleno-jewish tradition did not allow the essence and dynamics that the Gospel wanted to propagate emerged: equality for all. "There is neither Jew nor Gentile, neither slave nor free, nor is there male and female, for you are all one in Christ Jesus" (Gal., 3,28). ${ }^{14}$

In the birth of the Church, the Greek iconography highlights the presence of women, represented by Mary, in the cenacle. Then, after the Ascension, Mary of Nazareth became the first of all the others who came after her and had a visible spot of action in the Reign of God ${ }^{15}$. If Mary, from her "yes" became a Theotokos, the Mother of God gained a place that no man can occupy or even intended to reach, as Paul Evdokimov ${ }^{16}$, Slavicbyzantine theologian and historian reminded us.

If Peter was the head of the young community that was born in the cenacle, Mary, in turn, was its mother. Being the true mother of the community of disciples that formed the Mystical Body made the holy Fathers of the East to recognize as the mission of Mary's life, given by God and use this to explain and to be accomplices in the task of giving women a highlighted position in monasticism. Besides Mary, other women had

13. J. Breck, L'écriture dans la tradition [The Scriptures in the tradition] (Paris: Cerf Ed., 2013).

14. A. Louth, L'Eglise dans l'histoire. L'Orient grec et l'Occident latin [The church in history. The Greek East and the Latin West] (Paris: CERF Ed., 2012), 54.

15. F. Dupont, L'Antiquité, territoire des écarts. Entretiens avec Pauline Colonna d'Istria et Sylvie Taussig [Antiquity, territory of deviations. Interviews with Pauline Colonna of Istria and Sylvie Taussig] (Paris: Albin Michel, 2011), 17.

16. P. Evdokimov, A mulher e a salvação do mundo [The woman and the salvation of the world] (São Paulo: Paulinas Ed., 1986). 
important roles in the gospel narratives, making it clear that in the rising Church everybody had their own performing roles, even though they had no rights to stand out socially, according to the culture of the time. ${ }^{17}$

The Scriptures report that the number of families in which the woman was the first to confess the faith in the Risen One was very large. ${ }^{18}$ Paul speaks of Timothy whose father was a pagan, Greek, and his mother, Eunice, along with her grandmother, Loida, both Jewish, which embraced the faith and awakened in the son and grandson "a sincere faith" (2 Tim., 1, 5). Another example reported by Paul in Acts, when guided by the Holy Spirit he had come to Troas on the western shores of the Asia Minor. Uncertain about the region he should choose to evangelize, he felt called to move to Europe, where he began working on the Christianization of the West with a small group of women. Among these, the Apostle of the Nations named Lydia of Thyatira, the purple trader, who converted to Christianity along with her household who received baptism. Continuing on their mission trip, Paul has achieved great successes in converting women, both in Thessalonica and in Berea. (Acts 17, 12). As Lydia in Philippi, also Chloe in Corinth quickly joined with her family to the faith in Jesus Christ. Paul let the Corinthian Christians he knew about the conflicts that happened among them "by the house of Chloe" (I Cor., 1, 11). Because he was responsible for the new community, he did not hold back the source of the information. In another passage, Paul speaks then about twenty-six names of brothers and sisters in Jesus Christ, to whom, from Corinth, he sends greetings. Tops the list a couple, and the woman occupies the first place, what hurts attention, in the case of those times: "Greet Prisca and Aquila, my fellow workers in Christ Jesus" (I Corinthians 15: 3-5). ${ }^{19}$

Easily the early Church quoted the maternal figure, the woman of prayer who was standing beside the Cross, and in silent attitude, was prepared to receive the evangelizing mission of her Son, in the chalice from her hands raised. ${ }^{20}$ Gradually, the Church's maternal face left to prove in the way how Paul reported to the community of Galatians: "My dear children, for whom I am again in the pains of childbirth until Christ is formed in you, how I wish I could be with you now" (Gal 4: 19-20). As "Apostle of Christ" he would have been able to speak with authority to the Thessalonians. He preferred, however, to treat them "Just as a nursing mother cares for her children" (Ts 2,7). ${ }^{21}$

According to Christophe Levalois, based on the Holy Scripture, the Apostolic Constitutions of the Fourth Century and the Didascalia Apostolorum, in the Third Century, prescribed that bishops could also choose a faithful and saint deacon to serve other women in baptisms, for

17. L. H. Cooper, and A. Denny-Brown (eds) The Arma Christi in Medieval and Early Modern Material Culture. With a Critical Edition of "O Vernicle" (Farnham, Ashgate, 2014).

18. Ch. Guignebert, El Cristianismo primitivo, 1988.

19. Bíblia de Jerusalém, 2008.

20. Nissa, G. de. La mujer como evangelizadora, 1990].

21. Bíblia de Jerusalém. São Paulo, Paulus Editora, 2008. [Jerusalem Bible. São Paulo, Paulus Ed., 2008]. 
example. $^{22}$ The women helped in baptism and collaborated in the practice of charity to the bishop. Ready to obey, they were dedicated to visiting the sick, the disabled, widows and orphans. They were in the service of the Church, since they were reserved, discreet in speech, always kind, balanced, and could not make decisions without the permission of the bishop. ${ }^{23}$ However, they were different from the male priesthood, because they were assistants of the bishop. ${ }^{24}$ Moreover, the men provided the service on the occasions when the bishop couldn't. ${ }^{25}$

It became difficult to ascertain whether, from the beginning, the deaconess were distinguished from the widows, and what was the point or function that put them in different positions. Paul speaks repeatedly of widows. In the "sister Phoebe", he calls "diakonos of the Church of Cencris" (Rom. 16: 1). So, at that time, the feminine form of the word did not exist. Auxiliaries of both sexes are designated with the same title, and in many languages the masculine form of the word is still equally used for men and women. The fact that the Apostle require from the widows employed the same conditions (I Tim. 3: 11-13) which first had demanded of the deacons seems to indicate that in the beginning the work of deaconess was performed mainly by widows who had reached the prescribed age, whereas at a later stage a distinction between widows and deaconesses is stablished and virgins can perform such work. ${ }^{26}$

Like St. Paul, the Evangelists Mark and John record the presence of women as disciples and followers of Jesus (Mark 15.40 to 41; Jn 2.4; 19.26). In addition to the disciples, the so-called "widows" performed some roles in the Church of the first centuries, and even though there was no clear legislation on their roles and responsibilities. They lived in prayer and practice of continence. They deserved respect, helped the poor and took care of those who were sick. They made vows of chastity as virgins, and would be more than 50 years old for the bishop to receive them formally in the Church (Cf. Didascalia Apostolorum). ${ }^{27}$

In addition to the widows, another group of women took place in the Church: the virgins. Virginity was a form of perpetual life. It was embraced by the love of God and was a reflection of eternal life, where there was no longer the need for marriage. ${ }^{28}$ Such women consecrated themselves before

22. C. Levalois, Prendre soin de l'autre, 2012, 32.

23 Didascalia Apostolorum, In The Didascalia Apostolorum in English (Cambridge University Press, 2011), 1-13.

24 São Clemente De Alexandria, Pedagogo, 1, 4, 1-2, in História da Filosofia Cristã: Desde as Origens até Nicolau de Cusa, P. Boehner, E. Gilson, 7 a ed, transl. Raimundo Vier (Petrópolis: VOZES, 2000).

25 M. Spinelli, Helenização e recriação de sentidos. A Filosofia na época da expansão do Cristianismo - Séculos, II, III e IV [Helenization and the recreation of meanings. Philosophy at the time of Christianity's expansion - 2nd, 3rd and 4th Centuries] (Porto Alegre: Edipucrs Ed, 2002), 63-78.

26. Clauss, M. Alexandria. O destino de uma antiga metrópole [Alexandria. The destiny of an old metropolis] (Klett-Cotta: Stuttgart, 2004).

27. Didascalia Apostolorum, in The Didascalia Apostolorum in English (Cambridge University Pres, 2011) (Tertuliano, De exhort. 13, 4).

28. Patrística, Ambrósio de Milão [St. Ambrose of Milan] (São Paulo: Paulus, 1996). 
the bishop; they renounced temporal goods, wealth, luxury, vanities, and banquets. It was believed that those who are consecrated to God in their virginity were put in a close relationship with the Lord (2 Cor. 11.2). However, it demanded vigilance to avoid falling into pride. It was believed that the woman who renounced marriage was closer to the Holy Spirit, as the wife of Christ. ${ }^{29}$ However, in monastic life women who were mothers stood out, and in some cases, mothers and daughters lived in the same community, as in the example of St. Paula and her daughter Eustochium in the third century. ${ }^{30}$

The Holy Fathers inspired by the person of the Mother of God taught that every woman who professed her virginity was also a mother, because, although she had not had carnal relations they generated spiritual children to God. So, both married and virgin consecrated women were necessary and had their place in the history of salvation. ${ }^{31}$ If the virgins were usually under the orders of a bishop or a delegate priest, living communally under the spiritual direction of a "Mother" (experienced master in religious life) others, however, sought to approach God through the solitary life and demanding desert. ${ }^{32}$

The world's hiding places, even being first embraced by men, did not hinder the presence and female performance. In addition to the effort to accredit such a way of life including women, the Holy Fathers of Antioch, exponents of knowledge of mystical theology under the influence of the Cappadocian, were based on and took as references in the New Testament. They knew how to extract from the Pauline writings more than the mere admiration that the Apostle devoted to the first evangelizers women of Christianity, they extracted the substrate that would explain the unusual feat of giving space and visibility to women in the Church. ${ }^{33}$

The emergence of the female contemplative life in the Christian community was then explained by documentation, by written narratives that were later meticulously studied in its historicity by sacred researchers. Thus, thanks to the good care the sources received and the analyses developed by theologians and ancient mystics, apostolic times were par excellence a source that would respond to the emergence of issues related to qualify the place of women in monastic spaces. Thus, the Acts and the Epistles of St. Paul are also precious sources of knowledge of the doctrine of early Christianity about women and the services provided by them to the spring Christian communities. If the mission of Christ did not end with his earthly life, as stated in the Tradition and the Gospels, he became present in fragile human instruments represented by men and to carry out the task of those who had to make the church go on with its mission.

29. R. Treviano, Patrología [Patrology] Serie Sapientia Fidei (Madrid: BAC, 1994) 233.

30. Ch. Guignebert, El Cristianismo primitivo, 1988.

31. São Clemente De Alexandria, Stromata 3,86,1 e 88,2.3.

32. A. Camplani, G., Filoramo Foundations of power and conflicts of authority in late-antique monasticism, Proceedings of the International Seminar Turin, December 2-4 (Belgium: Peeters Publischers, 2007).

33. G. de Nissa, La mujer como evangelizadora, 1990, 4. 


\section{The Two Faces of Female Monasticism in the East}

After the Edict of Milan, the groups kept, in protest, to go to the desert, especially in Syria and Egypt, where Greek conquerors had gradually stifled the native culture. ${ }^{34}$ However, we cannot deny that religious incidence of Greek Eastern clerics gave a certain condition for the movement to have continuity and legitimacy as the clergy attributed an evangelical inspiration to that way of life.

In the development and organization of life, these movements of the desert took forward a demanding ascetic conception of baptism founded in continence, in poverty, in a life of prayers and a Judeo-Christian prophetic tradition that in Syria was concretized in the institution of the "children of the covenant". For the designation of those who followed this way of life,

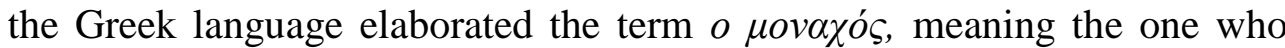
lives alone. Then a portion of those who left everything and shared the goods with their brothers came up, the coenobites. In the fourth century there was a mixture of two forms: semi-anchorite and semi-eremitic (semianacoreta and semieremítica. $)^{35}$

Anthony, Pachomius and Macarius from Egypt instilled an organization, a discipline and clerical way to such movements, awakening more and more vocations, especially in the Asia Minor and Constantinople. Even in Egypt, not all monks were reduced to eremitical and coenobitic models. The witnesses repeatedly spoke of irregular types that use of primitive anarchistic formulations, more unstable, tending to the practice of begging, not without intending to impose up to the bishops and people.

Right in the fourth century, Asia Minor and Constantinople witnessed an evolution that really did not depend on Egypt. By around 340, in Pontus, and through the deacon Marathonius, even in the capital, in the Macedonian time, Eustathius from Sebaste, guides a movement that conflicts with Eusebius of Nicomedia and with the official Church (Council of Gangra). The membership of Basil the Great into this group allowed a deeply evangelical and ecclesial evolution, in a distinctly coenobite way toward the service to the poor, disciplined work, the normal adoption of the priestly ministry and even the episcopate.

However, not only men lived a monastic way of life. St. John Chrysostom, describing the Letter of St. Matthew, said there are groups of women who lived in the desert and fought, just like men, a struggle against evil, against the devil, and the desires of the flesh. They called themselves "philosophers". $O \Phi_{l} \lambda \dot{o} \sigma o \varphi o \varsigma$, for the Greeks, particularly for the Stoics, was considered the perfect man, free from evil inclinations because they

34. P. Maraval, Constantin le Grand: Empereur romain, empereur chrétien (306-337) [Constantine the Great: Roman Emperor, Christian Emperor (306-337)] ( Paris: Éditions Tallandier, 2011)

35. M. Spinelli, Helenização e recriação de sentidos, 2002, 63-78. 
knew how to fight against it. The term in Christianity gained new semantics (gnosis) comprising one who had true knowledge of the doctrine of Christ. ${ }^{36}$

The Eastern Christian monks and ascetics took over this terminology to describe their way of life, saying that they followed the "true philosophy." Therefore, it is possible to conclude that the monks were called "true philosophers" to distinguish them from pagan 'pseudo-philosophers' who cultivated the philosophy of the world, taken by vain, and, therefore, considered dangerous for the monks. ${ }^{37}$ St. Basil and St. Gregory of Nyssa said if the monks were called 'philosophers', monasteries, in turn, were the "schools of philosophy", within which was taught the supreme philosophy of living life to God.

The Christian philosophy taught self-knowledge, balance, serenity, detachment from material things and encouraged the practice of virtues $\left(\Phi_{l} \lambda\right.$ ok $\left.\alpha \lambda i \alpha\right)$. The role of that 'true philosophy' was to lead the monk to the perception of sensible things, which raised the state of mind, facilitated meditation and could find ways to unite man to God so they could no longer be separated. ${ }^{38}$

Among the monastic learning, some of them stood out, sometimes because they fulfilled strictly the rules of life, sometimes due to their remarkable intelligence. The monk was considered perfect or "Abbot" when he could achieve "true philosophy", true wealth, true glory and true happiness, because he had become free from the power of material goods. For the monk, little was enough and the remains of that strictly necessary should be given to the exercise of charity. The "true philosopher", who dominated his tendencies, was the master of passions, spoke frankly to all, and helped the needy, preached by example, prayed and worked continuously, with the goal of perfection.

What to the followers of the "philosophy of the world" seemed to be a mere duty of humanitarianism, the Disciples of Christ had to carry as a service which was driven by higher motives. Their faith in the Risen Lord led them to the practice of charity. Therefore, the 'true philosophy' that men and women sought was that was achieved through a heroic effort to practice the evangelical counsels and perfection, which included the full and complete renunciation of worldly things, to love God alone. The search for the 'true philosophy' was not exclusive to monks who were in retreats in the desert or decided to live in monasteries. Many women also embraced this way of living. ${ }^{39}$

Among them was holy Macrina, sister of St. Gregory of Nyssa, the author of some writings which showed how his sister could get to 'true philosophy' and the true inner life, previously believed that only men could

36. P. Brown, Corpo e Sociedade: o homem, a mulher e a renúncia sexual no início do cristianismo [The Body and Society: man, woman and the sexual renunciation in early Christianity] Rio de Janeiro: Jorge Zahar, 1990).

37. Sozomeno, História eclesiástica [Ecclesiastical history], 1,13, 6, 33.

38. M. Spinelli, Helenização e recriação de sentidos, 2002, 69-73.

39. P. Deseille, Le monachisme orthodoxe: les principes et la pratique Typicon (règle de vie) du monastère Saint-Antoine-le-Grand [Orthodox monasticism: Typicon principles and practice (rule of life) of the Saint-Antoine-le-Grand monastery] (Paris: Cerf, 2013), 15. 
achieve. Macrina propagated and had a goal of thought that if because of sin, man and woman hurt the image of God, she and all of those who came to this 'true philosophy' - the monks and nuns - had the obligation to recover what was their original Creation. Therefore, it took the ongoing exercise, serenity and tranquillity ( $\dot{\eta} \sigma 0 \chi i \alpha)$ to reach the inner conversion ( $\mu \varepsilon \tau \dot{\alpha} v o l \alpha)$. According to St. Gregory, Macrina, which intended to do good, perfection and overcoming addictions to reach the imperturbability of the body and soul, gradually brought closer to her other women that, with her, formed a

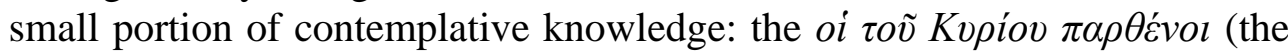
virgins of the Lord). Virginity that alluded the Greek term, in addition to right semantics, referred to the state of purity that every woman needed to get to so that "true wisdom" could be within her. ${ }^{40}$ Among them there were also those who have renounced the marriage and kept their virginity, dedicating their life to working for others, as Paul referred in the community of Corinth (I Cor. 7: 36-38).

St. Macrina and her disciples punctuated the constant search for spiritual perfection, however, even if that resulted in the abandonment of wills and the field of passions, it could not sacrifice the natural femininity of every woman, or deny it. It was necessary to enrich it and strengthen it so the image of God could be recovered and unadulterated. According to Gregory of Nyssa, his sister was a model of holiness to be followed, because in Macrina perfection was due to the philosophy of practice, which had as its goal the recovery of what sin tried to destroy: the image of God in his creation. ${ }^{41}$

In care to remain feminine, the nuns of Macrina glorified bodily wealth women not from the perspective of sensuality, corporeality, but the specificity that each woman had in relation to man. Women who were subject to their own experience of mystical faith, contributing to the formation of a female profile as specific as the monasticism followed by the early women of Pauline Christianity.

Therefore, the ascetic life had not intended to change the essence of creation, but dignify it in its wife's vocation in collaborative upturn mission of a virginal state. If the creation was virginally the image and likeness of God, to this vernacular they should return. The state of purity of the soul, fuelled by knowledge of the 'true philosophy', did not dispense with that the beauty or the adornments sustained by the body should be obliterated. It was a reflection and an optimized way of asceticism experienced by women who were accustomed to court life and, partially, tried to transplant to the monastic world customs practiced there under the aegis of a royal tradition. This female monasticism mode, inherited from the Byzantine monarchical tradition with all its princely props, was different, however, from the one that Mary of Egypt, for example, sought to herself.

40. A. Orbe, Introduction à la théologie des IIe et IIIe siècles [Introduction to the Theology of 2nd and 3rd Centuries] (Paris: Cerf Ed., 2012).

41. G. de. Nissa, La mujer como evangelizadora [The woman as evangelist] (Buenos Aires: Lumen Editorial, 1990). 
St. Mary of Egypt lived 47 years in the desert in austere penance, around the year 270, during the Emperor Claudius time. She was found by Abbot Zosima that went into the desert to seek advice from a hermit for his spiritual life. At the time of the meeting, Maria was naked and showed a gaunt body, sacrificed by exposure to the sun and intense fasting. If her nakedness was a reflection of the extreme detachment of unquestionable poverty and abnegation of female vanity, it was also the opposite of the materiality of what she had been as young girl. The writings on the life of Mary of Egypt talk about a twelve-year-old maiden who went to Alexandria, where she surrendered to public life, serving the pleasure of men. She went to Jerusalem with a group of sailors who wanted to revere the Cross of Christ, and as she had no money to pay for the trip, she used her body to honour the debt. After entering the Church and seeing the Cross, she got converted and went into the desert. In the austere desert life, she spent nearly half a century looking for herself and God, in a constant pilgrimage in search of holiness. If she lived in the lonely desert, the place and time pulled her youth, the freshness of her skin and the beauty with which she it did not take away her feminine condition: she was a woman. "Holy Abbot, do not look at me because I am naked, I'm a woman." ${ }^{42}$

The eremitical monastic profile of Mary of Egypt, with its extreme way of life when compared to coenobite Macrina, seems paradoxical. However, it reveals the specificities of the female monastic world with its nuances, the two legitimate ways to accredit the pursuit of perfection and "true philosophy", sometimes by the resurgence of a life guided by detachment and self-sacrifice, sometimes by the comfort of a community life in which sometimes they could take advantage of the benefits of a life not so radical. Both sides of eastern female monasticism were outlined and later developed to gain more defining colours and ways in other places.

It seems that the female monastic profile, cut in the mists of a nascent Church has fitted in accordance with the place of emergence; and thus the way to perceive the search for God and the life of its founders was adjusted again according to the requirements of time and performance spaces. Since St. Pachomius and Mary, his sister (third century), the Christian hermitages and monasteries testify the presence and action of the female face of Eastern monasticism, who also had space to develop in Western lands. ${ }^{43}$

St. Athanasius of Alexandria (295-373), for example, took the model of monastic life to the lands of Germany, when presenting the rules of monastic life compiled by St. Anthony. St. Augustine also wanted to repeat in Hippo a shared prayer life with his clergy and, this way, the male and female monasticism extended by Latin Africa having his mother, Santa Monica, as the first abbess. The first Western monks and nuns followed the style of coenobitic life in Lerins, in Gaul, with the exponents of St. Paulinus

42. J. de. Varazze, Legenda Áurea. Vida dos santos [Aurea Legend. The life of saints] (São Paulo: Cia das Letras, 2003), 354.

43. I. Gobry. Les moines en occident. Tome II. De saint Martin à saint Benôt [The monks in the west. Volume II. From Saint Martin to Saint Benedict] (Paris: Fayard, 1985). 
of Nola, St. Ambrose and St. Martin of Tours, who encouraged the emergence of women's prayer and detachment communities. ${ }^{44}$

In the sixth century, St. Benedict of Nursia, father in Western coenobite monasticism, propagated the monastic life throughout the West, starting with Rome and Naples. St. Scholastica, considered the twin sister and spiritual daughter of St. Benedict, founded in the West the female branch of the Order of Saint Benedict, based on the rules of the brother to run her monastery.

St. Basil, considered the Father of the Eastern monasticism, regulated and put order to the monastic life, inspired by the rules of St. Pachomius. Once restructured and appropriated for the time, the rules of St. Basil served for the compilation and planning of female life model, guided by Macrina, coming to the West in the several female monastic communities.

If in the early Church the desert was the emblematic place for seeking interiority, the later centuries showed that community life in the company of its peers was as challenging as the experience in the desert. Because living with it is not always easy and sometimes it is a tightrope walk that has to be followed, without spaces for any exception. If the place of asceticism looked upon the face of God through the desert aridity, many holy women have experienced this in a face to face experience, by living in the community, the common observance of rules and schedules, as well as in the collective dedication to the poor and beggars. The maternal face of God gained flesh as the nun, without losing what was specific to her feminine essence, showed that fraternal love and without measures found in monkish face a way to come to the light.

The desert was not the place of predilection and the space that Christian women of the early centuries chose to live for God. A lot of them chose their own homes, bringing with them daughters and relatives to form a community of prayer. It amazes us that St. Pachomius has founded a hundred monastic houses, totalling seven thousand monks and nuns. It is necessary to relativize the coenobitism and observe the common reality that sometimes the coenobitic life happened in the family, and it cannot be said that the holiness and prayer life did not exist.

About this peculiarity, Antônio Orbe shows us that this contemplative way of life was due to the custom which families had to gather to pray in secret fearing Christian's persecution. The constant exercise of escaping, family in reclusion, unfolded in a collective devotional arrangement that came to develop the family coenobitism, with the mother, when a widow, as the great Abbess. ${ }^{45}$

44. J. A. Besen, Pais e mães do deserto: atletas de Deus [Fathers and mothers of the desert: athletes of God] (Florianópolis: Mundo e Missão, 2005).

45. A. Orbe, Introduction à la théologie des IIe et IIIe siècles, 2012. 


\section{Conclusion}

Discussing about the female monastic life in the East was, through the use of sources and patristic writings, a precious path taken by the Church and that came to contemporary times, beyond a forceful call to holiness, to rediscover the role of women in the making and unfolding of the contemplative life. Given the rereading of the monastic life of women, researchers should restructure positions and value to so many women who have contributed in their own way to the continuity of monastic life.

The proliferation of female monastic life in the Christian East, from Western Europe to Eastern Europe, indicates the existence of people who still resist the world's call to respond freely to God's call. In predominantly Christian countries of Byzantine tradition currently stand out numerous female monasteries in Greece, Romania, Russia, Ukraine and Poland which still keep the coenobites rules inherited from the time of the founder. In these monasteries, the cassock, although hiding the woman's body almost completely, do not hide the femininity of every woman.

In Brazil, the female monastic life of portion and Byzantine tradition is still alive, but in a few monasteries under the jurisdiction of the Melkite Catholic Church, Orthodox Church of Poland and Serbia and Ukrainian Greek Catholic Church. However, it was the western Benedictine order that founded more vocations and fertile ground to develop, spreading in almost all the country's dioceses. Eastern Byzantine or Western Latin tradition, female monasteries present in Brazil seek, each with their charisms and challenges, preserve what they inherited from the Fathers and Mothers of the Desert: the wisdom of time and waiting. Many holy women who quietly and steadily testify that in "their deserts" they found the "true philosophy" taught by the Christ, who they always seek to be faithful. This form of evangelization, of silence and prayer, also brings benefits to the whole Church, which once was born in the East but which is present in every community of faith.

\section{Bibliography}

Amaral, R. A santidade habita o deserto: hagiografia à luz do imaginário social [The holiness inhabits the desert: hagiografy in the life of the social imaginary]. São Paulo: Ed UNESP, 2009.

Besen, J. A. Pais e mães do deserto: atletas de Deus [Fathers and mothers of the desert: athletes of God]. Florianópolis: Mundo e Missão, 2005.

Bíblia de Jerusalém [Jerusalem Bible]. Sao Paulo: Paulus Ed., 2008.

Breck, J. L'écriture dans la tradition [The Scriptures in the tradition]. Paris: Cerf Ed., 2013.

Brown, P. Corpo e Sociedade: o homem, a mulher e a renúncia sexual no início do cristianismo [The Body and Society: man, woman and the sexual renunciation in early Christianity]. Rio de Janeiro: Jorge Zahar, 1990.

Brown, P. "The rise and function of the Holy Man in late antiquity." In Journal of Roman Studies 61(1971): 80-101. 
Camplani, A. Filoramo G. Foundations of power and conflicts of authority in lateantique monasticism. Proceedings of the International Seminar Turin, December 2-4. Belgium, Peeters Publischers, 2007.

Clauss, M. Alexandria. $O$ destino de uma antiga metrópole [Alexandria. The destiny of an old metropolis]. Klett-Cotta: Stuttgart, 2004.

Colombas, G. M. El monacato primitivo [The primitive monasticism]. Madrid: Christian Authors Library, 2004.

Cooper, L. H., and A. Denny-Brown (eds.). The Arma Christi in medieval and early modern material culture. With a critical edition of ' $O$ Vernicle'. Farnham: Ashgate, 2014.

Deseille, P. Le monachisme orthodoxe: les principes et la pratique Typicon (règle de vie) du monastère Saint-Antoine- le-Grand [Orthodox monasticism: Typicon principles and practice (rule of life) of the Saint-Antoine-le-Grand monastery]. Paris: Cerf, 2013.

Didascalia Apostolorum, In The Didascalia Apostolorum in English. Cambridge University Pres, 2011. (Tertuliano, De exhort. 13, 4).

Dupont, F. L'Antiquité, territoire des écarts. Entretiens avec Pauline Colonna d'Istria et Sylvie Taussig [Antiquity, territory of deviations. Interviews with Pauline Colonna of Istria and Sylvie Taussig]. Paris: Albin Michel, 2011.

Evdokimov, P. A mulher e a salvação do mundo [The woman and the salvation of the world]. São Paulo: Paulinas Ed., 1986.

Gobry, I. Les Moines en Occident. Tome II. De saint Martin à saint Benoît [The Monks in the West. Volume II. From Saint Martin to Saint Benedict]. Paris: Fayard Ed., 1985.

Guignebert, Ch. El Cristianismo primitive [The primitive cristianity]. Mexico: Economic Culture Fund, 1988.

Knitter, P. F. Introduzione alle teologie delle religioni [Introduction to the Theology of religion]. Rome: Queriniana, 2012.

Levalois, C. Prendre soin de l'autre: une vision chrétienne de la communication [Taking care of others: a Christian vision of communication]. Paris: CERF Ed., 2012.

Louth A. L'Eglise dans l'histoire. L'Orient grec et l'Occident latin [The church in history. The Greek East and the Latin West]. Paris: CERF Ed., 2012.

Maraval, P. Constantin le Grand: Empereur romain, empereur chrétien (306-337). [Constantine the Great: Roman Emperor, Christian Emperor (306-337)]. Paris: Éditions Tallandier Ed., 2011.

Masoliver, A. Historia del monacato cristiano. I. El monacato desde los origines hasta san Benito [The History of the Christian Monasticism. I. The monasticism from its origins until St. Benedict]. Madrid: Encuentro Ed, 1994.

Masoliver, A. Historia del monacato cristiano, III. El monacato Oriental. El monacato feminino [The History of the Christian Monasticism. III. The Eastern Monasticism. The Female Monasticism]. Madrid: Encuentro Ed, 1994.

NISSA, G. de. La mujer como evangelizadora [The woman as evangelist]. Buenos Aires: Lumen Ed, 1990.

Orbe, A. Introduction à la théologie des IIe et IIIe siècles [Introduction to the Theology of 2nd and 3rd Centuries] Paris: Cerf, 2012.

Patrística. Ambrósio de Milão [St. Ambrose of Milan]. São Paulo: Paulus, 1996.

Rapp, C. Holy Bishops in late antiquity: the nature of christian leadership in an age of transition. The Transformation of the Classical Heritage, 37. Berkeley and Los Angeles: University of California Press, 2005. 
São Clemente De Alexandria, Pedagogo, 1, 4, 1-2. In História da Filosofia Cristã: Desde as Origens até Nicolau de Cusa, P. Boehner, E. Gilson, 7 a ed. Translated by R. Vier. Petrópolis: Vozes, 2000.

São Clemente De Alexandria. Stromata 3,86,1 e 88,2.3.

Sozomeno, História eclesiástica [Ecclesiastical history], 1,13, 6, 33.

Spinelli, M. Helenização e recriação de sentidos. A Filosofia na época da expansão do Cristianismo - Séculos, II, III e IV [Helenization and the recreation of meanings. Philosophy at the time of Christianity's expansion 2nd, 3rd and 4th Centuries] (Porto Alegre: Edipucrs Ed, 2002), 63-78.

Treviano, R. Patrología [Patrology]. Série Sapientia Fidei. Madrid: BAC, 1994.

Varazze, J. de. Legenda Áurea. Vida dos santos [Aurea Legend. The life of saints]. São Paulo: Cia das Letras, 2003. 